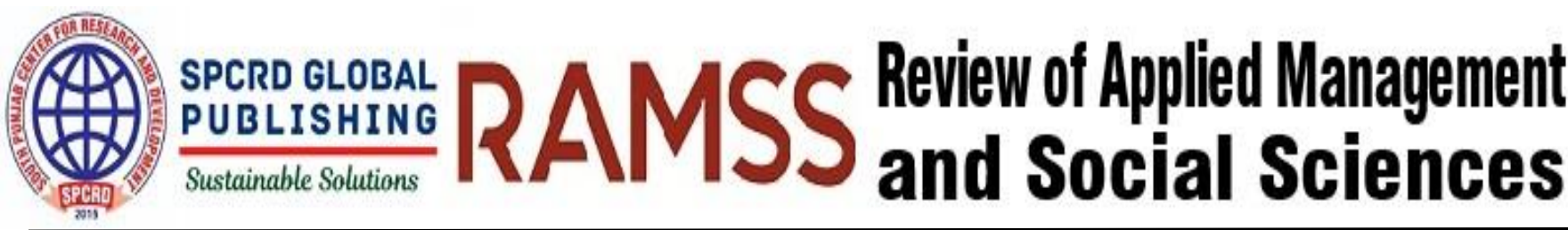

\section{Impact of Ownership Structure on Earnings Management: Evidence from Pakistan}

\author{
a Amir Rafique, buhammad Hanif Akhtar, ${ }^{\mathrm{c}}$ Muhammad Umer Quddoos, \\ d Sher Dil Khan Jadoon
}

\begin{abstract}
${ }^{a}$ Assistant Professor, Department of Management Sciences, COMSATS University Islamabad, Pakistan amir.rafique@comsats.edu.pk

${ }^{\mathrm{b}}$ Department of Commerce, Bahauddin Zakariya University, Multan, Pakistan.

haneefakhtar@gmail.com

c. Assistant Professor, Department of Commerce, Bahauddin Zakariya University, Multan, Pakistan.umerattari@bzu.edu.pk

d. MS Scholar, Department of Management Sciences, COMSATS University Islamabad, Pakistan

sdkjadoon@gmail.com
\end{abstract}

Corresponding author's email address: haneefakhtar@gmail.com

\begin{tabular}{l}
\hline ARTICLE DETAILS \\
\hline History: \\
Accepted 19 December 2018 \\
Available online 31 December \\
2018 \\
\hline Keywords: \\
Pakistan Stock Exchange, \\
Earnings Management, \\
Institutional Ownership, \\
Foreign Ownership \\
\hline JEL Classification: \\
B26, G32, M11 \\
\hline
\end{tabular}

DOI: $10.47067 /$ ramss.v1i1.34

\section{ABSTRACT}

The aim of the current study is to examine the impact of ownership structure on earnings management by using three aspects of ownership i.e. managerial, institutional and foreign. The sample consists of non-financial firms included in KSE-100 index of Pakistan Stock Exchange (PSX). The modified Jones model is used to calculate earnings management and random effect model regression is applied to test the impact of ownership structure on earnings management. The findings reveal that firms with high managerial and foreign ownership, engage more in earnings management. However, analysis reveal insignificant relationship between institutional ownership and earnings management.

(C) 2019 The authors. Published by SPCRD Global Publishing. This is an open access article under the Creative Commons Attribution-

NonCommercial 4.0

\section{Introduction}

It is essential for the investors that the information published in the financial statements is representing the true picture of the firms' financial performance, because investors usually make investment decisions accordingly. However, the quality of the financial reports is highly dependent on whether managers manipulate earnings or not. Therefore, managers' motives to manipulate earnings may distort the quality of the financial reporting. As per Healy and Wahlen (1999), the use of personal 
judgment by managers' in structuring financial reporting, for any purpose like to mislead shareholders about the actual economic performance of the firm is known as earnings management. In recent years, world has witnessed many accounting scandals such as Enron, Tyco International, WorldCom and Olympus Corporation merely because of earnings management. Thus, to protect stakeholders' interest from the negative effects of earnings management and to improve the transparency of financial reports, firms include corporate governance mechanisms in the financial reporting process (Rezaee 2005). Governance mechanisms is to assure the transparency of the reporting process.

Prior literature has indicated that corporate governance factors have an effect on earnings management (Bushman et al. 2004; Cornett et al. 2008; Dechow et al. 1996). For example, Klein (2002) state that due to audit committee independence chances of earnings manipulations are less . Warfield et al. (1995) and Alves (2012) document that if managerial ownership in the firm is high there will be lower magnitude of earnings management. Chung, Firth, and Kim (2002) state that institutional investors are more resourceful in detecting earnings management than individuals, therefore high percentage of institutional ownership reduce earnings management. Although there are various corporate governance factors, agency theory suggests that ownership structure can provide more active monitoring and proved to discipline manager's activities (Reyna 2012). Ownership structure can impact earnings management both positively and negatively (Bertin et al. 2008). Based on importance of ownership structure for earnings management, the study aims at checking the impact of three ownership types i.e. managerial and institutional ownerships on earnings management in Pakistan.

Furthermore, review of literature shows that foreign ownership has not gained as much attention as other corporate governance mechanism. Thus, inclusion of foreign ownership along with managerial and institutional ownership in this study is valuable not only in Pakistan but also for other developing countries. Thus, this study provides new insights by investigating three segments of ownership structure; (i) managerial ownership, (ii) institutional ownership and (iii) foreign ownership, and their impact on earnings management in the non-financial firms included in KSE-10o index of Pakistan Stock Exchange (PSX).

\section{Literature Review and Hypotheses Development}

Jensen and Meckling (1976) describe the relationship between managers and owners of the firms as "pure agency relationship", which is related to the divergence of ownership and control. Arnold and de Lange (2004) say that agency relationship exist when principals (shareholders) hire agents (managers) to make decisions and perform tasks that maximizes their wealth. The agency problem becomes aggravated in the presence of information asymmetry. Both managers and shareholders have different levels of information, usually managers have more information as compared to shareholders (Mallin 2013). Therefore, earnings management occurs because of the opportunistic behavior by managers and due to more information with managers, which refers as agency cost. Managers can show the earnings in an optimistic way by altering the accrual methods, as these methods require estimations and judgments for preparing financial statements (Enomoto et al. 2015). Agency theory suggests that a strong governing mechanism improves the accuracy of the financial reports (Jensen and Meckling 1976).

The major objective of the governance mechanism is to align shareholders' and managers' interests and to protect the rights and investment of the shareholders. Corporate governance is required for the credibility of the financial reports and also ensures that financial statements are in compliance with international financial accounting standards by monitoring the reporting process (Bushman and Smith 2003). According to Siregar and Utama (2008) ownership structure of the corporation has potential to 
limit the earnings management activities. Agency theory also advocates that the ownership structure can provide more active monitoring and proved to discipline firm manager's activities (Reyna 2012). In this paper managerial, institutional and foreign ownership is being taken as the proxies of ownership structure and investigate the association and the impact of these three proxies on earnings management in Pakistan.

The literature discusses two opposing views about the influence of managerial ownership on opportunistic behavior of the managers, first is alignment of interest and second is entrenchment (Dechow et al. 2010; Yeo et al. 2002). The alignment of interest hypothesis state that, shareholding by managers' helps in aligning managers and stakeholder interests (Jensen and Meckling 1976). On the other hand, entrenchment hypothesis states that greater managerial ownership may put managers' in dominant position and hence, greater freedom for opportunistic behavior (Morck, Shleifer, and Vishny 1988).

\section{Research Methodology}

The sample consists of non-financial firms which are part of KSE-10o Index of the Pakistan Stock Exchange (PSX). The time span of the sample runs from 2009 to 2015 . However, financial firms are not included in the final sample because the accrual behavior and regulations of the financial firms are different from non- financial firms (Klein 2002), (Roodposhti and Chashmi 2011). All the data required computing the ownership structure (i.e. the proportion of shares held by managers, institutions and foreign investors), to estimate discretionary accruals and to compute leverage and firm growth is collected from financial statements of the companies. All financial statements are obtained from the respective companies' websites.

\section{III.1 Variables and Their Measures}

\section{III.1.1 Earnings Management}

Discretionary accruals are at the discretion of managers and are the mostly used proxies to estimate the earnings management. The standard methodology of Modified-Jones model is applied to estimate the discretionary accruals. The Modified-Jones model is as follows:

$\frac{T A C C_{i t}}{T A_{i t-1}}=\beta_{1}\left(\frac{1}{T A_{i t-1}}\right)+\beta_{2}\left(\frac{\Delta \operatorname{Rev}_{i t}-\Delta R e c_{i t}}{T A_{i t-1}}\right)+\beta_{3}\left(\frac{P P E_{i t}}{T A_{i t-1}}\right)+\varepsilon_{i t}$

Where,

TACC $=$ total accruals (TACC $=$ Net Income - Cash Flows from Operations).

$\Delta R e v=$ Changes in revenue.

$\Delta R e c=$ Changes in receivables.

$\mathrm{PPE}=$ Plant property, and equipment.

$\mathrm{TA}=$ Total assets at $\mathrm{t}$.

\section{III.1.2 Independent Variables}

Managerial ownership is computed as actual percentage of common stock owned by managers. Whereas institutional ownership is basically the portion of ownership held by institutions. We use a dummy variable to calculate foreign ownership, being 1 if foreign investors held at least $5 \%$ common 
stock of the firm and o otherwise.

\section{III.1.3 Control Variables}

Ownership structure is not the only factor that has an impact on earnings management. Therefore, it is essential to control the effect of other relevant variables while evaluating the relationship between the two variables. Therefore, following DeFond and Jiambalvo (1994), Dechow et al. (1995) and Klein (2002), leverage (measured as debt to asset ratio), firm growth (measured as changes in lagged total assets) and financial performance (measured as ROA) are included as a control variables in this study.

\section{III.2 Regression Model}

The final step of the analysis is to perform the final regression to test the hypothesis. Following regression will be employed to identify the association among dependent and independent variables:

$$
\begin{aligned}
& \operatorname{DACC}_{i t}=\beta_{0}+\beta_{1}\left(M_{O} O W N_{i t}\right)+\beta_{2}\left(I O W N_{i t}\right)+\beta_{3}\left(F O W N_{i t}\right)+\beta_{4}\left(\text { Lev }_{i t}\right)+\beta_{5}\left(\text { Growth }_{i t}\right)+ \\
& \beta_{6}\left(\text { ROA }_{i t}\right)+\varepsilon_{i t}
\end{aligned}
$$

Where,

$D A C C_{i t}=$ Absolute Discretionary Accruals.

$M O W N_{i t}=\%$ of shares owned by managers.

$I O W N_{i t}=\%$ of shares owned by institutional investors.

$F O W N_{i t}=$ dummy variable, 1 if there is share of foreign investors is more that $5 \%$ in the common stock, and o otherwise.

$L e v_{i t}=$ debt to assets ratio, it is leverage.

Growt $_{\text {it }}=$ Percentage change in total assets.

$R O A_{i t}=$ Net income divided by Total Assets.

$\varepsilon_{i t}=$ error term.

$\beta_{0}$ is a constant, $\beta_{1}$ to $\beta_{6}$ are the coefficients.

\section{Data Analysis and Results}

The descriptive statistics show that mean values of managerial ownership, institutional ownership and foreign ownership are $14.83 \%, 43.00 \%$, and $49.88 \%$ respectively. The mean value of institutional ownership is higher than both UK and US firms, for instance Peasnell, Pope, and Young (2005) find 24\% institutional ownership in UK and $\mathrm{Yu}$ (2008) finds out $41 \%$ institutional ownership in the US. Foreign ownership is proxied by dummy variable, therefore, its mean value indicating that around $50 \%$ of the firms have foreign investors who have more than $5 \%$ common stock of the company.

Table 1: Correlation Matrix

\begin{tabular}{llllllll} 
& DACC & MOWN & IOWN & FOWN5 & LEV & GROWTH & ROA \\
\hline DACC & 1 & & & & & \\
MOWN & 0.0049 & 1 & & & & \\
IOWN & -0.0164 & -.451 & 1 & & & \\
FOWN5 & 0.0550 & -.236 & -0.452 & 1 & & \\
LEV & 0.0922 & -.095 & 0.1833 & -0.185 & 1
\end{tabular}


$\begin{array}{lllllll}\text { GROWTH } & 0.2694 & -0.008 & -0.0578 & -0.017 & 0.0167 & 1\end{array}$

$\begin{array}{llllllll}\text { ROA } & 0.3806 & 0.0021 & -0.1452 & 0.1534 & -0.303 & 0.0123 & 1\end{array}$

Where, ABSDACC = Absolute Discretionary Accruals, MOWN = Managerial ownership, IOWN = Institutional ownership, FOWN = Foreign Ownership, LEV = Leverage, and

Growth $=$ Firm Growth

Number of Observations: 427

Period: 2009 - 2015

Table 1 shows that none of the variable has correlation more than 0.8 which means that there is no case of multicollinearity. Furthermore, managerial ownership and foreign ownership have positive correlation with discretionary accruals. However institutional ownership has negative correlation with discretionary accruals.

Table 2: Fixed Effect Model Results

\begin{tabular}{lcccc}
\multicolumn{1}{c}{ Variable } & Coefficient & Std. Error & t-Statistics & Prob. \\
\hline C & -0.098942 & 0.026284 & -3.764409 & $0.0002^{* * *}$ \\
MOWN & 0.064783 & 0.033088 & 1.957891 & $0.0509^{*}$ \\
IOWN & 0.040488 & 0.026626 & 1.520594 & 0.1291 \\
FOWN & 0.027778 & 0.013597 & 2.042881 & $0.0417^{* *}$ \\
LEV & 0.148081 & 0.026046 & 5.685342 & $0.0000^{* * *}$ \\
GROWTH & 0.078237 & 0.010179 & 7.685882 & $0.0000^{* * *}$ \\
ROA & 0.590843 & 0.048285 & 12.23670 & $0.0000^{* * *}$
\end{tabular}

Weighted Statistics
R-squared
0.320356
Adjusted R-squared
0.310646
F-statistic
32.99503
Prob(F-statistic)
0.000000

Note: ${ }^{* *}, * *$, denote the level of significance at $1 \%, 5 \%$ and $10 \%$ respectively.

Where, DACC = Discretionary Accruals, MOWN = \% Shares of Managers, IOWN $=\%$ Shares of Institutional Ownership, FOWN = Dummy variable for Foreign investors, LEV = Leverage, GROWTH = Firm Growth, ROA= Firm Performance

Number of Observations: $427 \quad$ Period: $2009-2015$

The value of Adjusted R-square is 0.3106, which suggests that 31.06\% discretionary accruals are explained by the combined variation in managerial ownership, institutional ownership, foreign ownership, leverage, firm growth and firm performance. R-square value is a bit low but according to Peasnell, Pope, and Young (200ob), low R-square value is acceptable in studies using discretionary accruals. Results show that managerial and foreign ownership are significantly positive at $10 \%$ and $5 \%$ level respect*tively. Positive relationship of managerial ownership with the absolute discretionary accruals is consistent with "entrenchment hypothesis". Further, this association is in line with those found by Morck, Shleifer, and Vishny (1988), Al-fayoumi, Abuzayed, and Alexander (2010), and Charfeddine, Riahi, and Omri (2013). In contrast, managerial ownership is inconsistent with the 
"alignment of interest hypothesis". However, institutional ownership is positive but insignificant. Possible reasoning of this insignificant relationship might be the lack of investment companies and welldeveloped asset management companies in Pakistan. The result for institutional ownership is consistent with those found by Al-fayoumi et al. (2010), Koh (2003) and Siregar and Utama (2008) and find its justification in transient investor arguments, which argues that the institutional investors follow shortterm approach and are more focused on current earnings therefore generate motivations for earnings management. Leverage (LEV), growth and return on Assets (ROA) are significantly positive at $1 \%$ level of significance.

\section{Conclusions and Recommendations}

The objective of the study is to examine the relationship among earnings management and three types of ownership structures. The earnings management phenomenon has significance in influencing stakeholders everywhere throughout the globe. Main motivation of this study is the availability of limited literature on the association of earnings management and ownerships structure in Pakistan. In addition to the above, there is a lack of consensus in the literature regarding the relationship. The results of managerial ownership show that when managers have high stake in the company, managers act opportunistically to get involved in accruals manipulations for personal gains. The findings reveal that the existence of institutional investors is not found to be an effective monitoring mechanism for mitigating the earnings management in Pakistan. The findings further reflect that foreign investors tend to play a significant role in mitigating the manipulations in accruals but support the argument that managers, in order to attract foreign investments, tend to get involved in earnings management.

The results validate agency theory predictions that ownership structure is an effective monitoring mechanism for earnings management. The positive relationship between absolute discretionary accruals and managerial ownership found in this study supports the argument that if mangers have their own share in the earnings, they tend to get indulged more in the earnings management activities. Similarly, results of foreign ownership reveal that presence of foreign investors motivates managers to do earnings manipulation to attract more foreign investment. In terms of extant literature, foreign ownership has not gained as much attention as other corporate governance mechanism. Nonetheless, significant results of foreign ownership found in this study are valuable for the researchers investigating earnings management not only in Pakistan but in general. The evidence shows that managerial and foreign investors are putting upward pressure on discretionary accruals. Therefore, revisions may be made in corporate governance act and a limit on maximum shareholdings, by the managers, may be in place. Further, this research suggests that accruals manipulations are detectible and can be challenged by the auditors, investors and the regulators. Hence, investors need to consider the earnings management through accruals manipulation before making their investment decisions.

Future research can be conducted by decomposing the institutional ownership into ownership by financial institutions and that by joint stock companies. Board size, audit quality, audit tenure, and CEO duality could also be used along with the ownership structures to measure their impact on discretionary accruals.

\section{References}

Al-fayoumi, N., Abuzayed, B. and Alexander, D., 2010. Ownership Structure and Earnings Management in Emerging Markets : The Case of Jordan. International Research Journal of Finance and Economics, 38(38), pp.28-47.

Alves, S., 2012. Ownership Structure and Earnings Management : Evidence from Portugal. Australian Accounting Business and Finance Journal, 6(1), pp.57-74. 
Arnold, B. and de Lange, P., 2004. Enron: An examination of agency problems. Critical Perspectives on Accounting, 15(6-7), pp.751-765.

Bertin, M.J., Iturriaga, F.J.L. and Foronda, Ó.L. de, 2008. The contest to the control in European family firms: How other shareholders affect firm value. Corporate Governance, 16(3), pp.146-159.

Bushman, R. et al., 2004. Financial accounting information, organizational complexity and corporate governance systems,

Bushman, R.M. and Smith, A.J., 2003. Transparency, Financial Accounting Information, and Corporate Governance. Economic Policy Review, 9(April), pp.65-87.

Charfeddine, L., Riahi, R. and Omri, A., 2013. The Determinant of Earnings Management in Developing Countries : A study of the Tunisian Context . IUP Journal of Corporate Governance, 12(1), pp.35-49.

Cheng, C.S.A. and Reitenga, A., 2009. Characteristics of institutional investors and discretionary accruals. International Journal of Accounting and Information Management, 17(1), pp.5-26.

Chung, R., Firth, M. and Kim, J.B., 2002. Institutional monitoring and opportunistic earnings management. Journal of Corporate Finance, 8(1), pp.29-48.

Cornett, M., Marcus, A. and Tehranian, H., 2008. Corporate governance and pay-for-performance: The impact of earnings management. Journal of Financial Economics, 87(2), pp.357-373. Available at: http://linkinghub.elsevier.com/retrieve/pii/So304405X07001651.

Dechow et al., 1996. Causes and Consequences of Earnings Manipulation- An Analysis of Firms Subject to Enforcement Actions by the SEC. Contemporary Accounting Research, 13(1), pp.1-36.

Dechow, P., Ge, W. and Schrand, C., 2010. Understanding earnings quality: A review of the proxies, their determinants and their consequences. Journal of Accounting and Economics, 50(2-3), pp.344401. Available at: http://dx.doi.org/10.1016/j.jacceco.2010.09.001.

Dechow, P.M., Sloan, R.G. and Sweeney, A.P., 1995. Detecting Earnings Management. The Accounting Review, 70(2), pp.193-225.

DeFond, M.L. and Jiambalvo, J., 1994. Debt covenant violation and manipulation of accruals. Journal of Accounting and Economics, 17(1-2), pp.145-176.

Enomoto, M., Kimura, F. and Yamaguchi, T., 2015. Accrual-based and real earnings management: an international comparison for investor protection. Journal of Contemporary Accounting and Economics, 11(3), pp.183-198. Available at:

http://www.sciencedirect.com/science/article/pii/S1815566915000235.

Healy, P.M. and Wahlen, J.M., 1999. A Review of the Earnings Management Literature and Its. Accounting Horizons, 13(4), pp.365-383.

Jensen, M.C. and Meckling, W.H., 1976. Theory of the Firm : Managerial Behavior , Agency Costs and Ownership Structure. Journal of Financial Economics, 3(4), pp.305-36o.

Jones, J.J., 1991. Earnings Management During Import Relief Investigations. Journal of Accounting Research, 29(2), pp.193-228.

Klein, A., 2002. Audit committee, board of director characteristics, and earnings management. Journal of Accounting and Economics, 33(3), pp.375-400.

Koh, P.-S., 2003. On the association between institutional ownership and aggressive corporate earnings management in Australia. The British Accounting Review, 35(2), pp.105-128. Available at: http://linkinghub.elsevier.com/retrieve/pii/So890838903000143. 
Mallin, C.A., 2013. Corporate Governance, Oxford University Press.

Morck, R., Shleifer, A. and Vishny, R.W., 1988. Management Ownership and Market Valuation - An Empirical Analysis. Journal of Financial Economics, 20(1-2), pp.293-315.

Peasnell, K. V., Pope, P.F. and Young, S., 2005. Board monitoring and earnings management: Do outside directors influence abnormal accruals? Journal of Business Finance and Accounting, 32(7-8), pp.1311-1346.

Peasnell, K.V., Pope, P.F. and Young, S., 2000. Detecting earnings management using cross- sectional abnormal accruals models Detecting earnings management using cross-sectional abnormal accruals models. Accounting and Business Research, 30(4), pp.313-326.

Reyna, J.M.S.M., 2012. An Empirical Examination of Ownership Structure, Earnings Management and Growth Opportunities in Mexican Market. International Journal of Business and Social Research, 2(7), pp.103-123.

Rezaee, Z., 2005. Causes, consequences, and deterence of financial statement fraud. Critical Perspectives on Accounting, 16(3), pp.277-298.

Roodposhti, F.R. and Chashmi, S.A.N., 2011. The impact of corporate governance mechanisms on earnings management. African Journal of Business Management, 5(11), pp.4143-4151. Available at: http://www.academicjournals.org/AJBM.

Siregar, S.V. and Utama, S., 2008. Type of earnings management and the effect of ownership structure, firm size, and corporate-governance practices: Evidence from Indonesia. The International Journal of Accounting, 43(1), pp.1-27.

Warfield, T.D. et al., 1995. Managerial ownership, accounting choices, and informativeness of earnings. Journal of Accounting and Economics, 20(1), pp.61-91.

Yeo, G.H.H. et al., 2002. Corporate ownership structure and the informativeness of earnings. Journal of Business Finance and Accounting, 29(7-8), pp.1023-1046.

Yu, F., 2008. Analyst coverage and earnings management \$. Journal of Accounting and Economics, 88, pp.245-271. 